\title{
PENGEMBANGAN PROTOTIPE SISTEM INFORMASI MANAJEMEN PRESTASI DAN BEASISWA UNDIKSHA (PRABA)
}

\author{
I Made Ardwi Pradnyana ${ }^{1}$, Agus Aan Jiwa Permana ${ }^{2}$ \\ ${ }^{1} J u r u s a n$ Pendidikan Teknik Informatika, Universitas Pendidikan Ganesha \\ Singaraja, Indonesia \\ ${ }^{2}$ Jurusan Manajemen Informatika, Universitas Pendidikan Ganesha \\ Singaraja, Indonesia
}

e-mail: ardwi.pradnyana@undiksha.ac.id, agus.aan@undiksha.ac.id

\begin{abstract}
Abstrak
Dokumentasi dan manajemen data prestasi dan beasiswa masih menjadi masalah krusial yang harus segera diselesaikan. Jika dibiarkan, masalah tersebut dapat mengganggu pengelolaan perguruan tinggi saat ini dan kedepannya. Penelitian ini merupakan penelitian pengembangan yang menghasilkan prototipe Sistem Informasi Manajemen Prestasi dan Beasiswa Undiksha (PRABA). Prototipe PRABA berhasil dikembangkan melalui metode pengumpulan data dan studi literatur, analisis dan perancangan serta implementasi dan pengujian. Pengumpulan data dilakukan dengan metode wawancara dan mengkaji dokumen beasiswa. Studi literatur dilakukan dengan mempelajari dasar teori mengenai diagram use case dan aktivitas serta perancangan basis data dengan ERD. Analisis dilakukan untuk mendapatkan kondisi yang selama ini terjadi (As Is). Kemudian penulis merumuskan syarat fungsional yang harus dimiliki sistem untuk menangani kendala yang terjadi saat ini. PRABA diimplementasikan berbasis website dengan bahasa pemrograman PHP dan basis data MySQL. Hasil pengujian terhadap PRABA menggunakan metode pengujian black box menunjukkan bahwa PRABA sudah memenuhi syarat fungsionalitas yang sudah ditetapkan terkait manajemen data prestasi dan beasiswa.
\end{abstract}

Kata kunci: Prestasi, Beasiswa, Sistem Informasi Manajemen

\begin{abstract}
Documentation and management of achievement data and scholarship remains a crucial issue that must be resolved soon. If this problem is not addressed, it may disrupt the management of the college now and in the future. This research is a development research that produces prototype of Sistem Informasi Manajemen Prestasi dan Beasiswa Undiksha (PRABA). The PRABA prototype was successfully developed through the stages of data collection and literature study, analysis and design as well as implementation and testing. Data collection is done by interviewing method and reviewing scholarship documents. Literature study is done by studying the basic theory about use case and activity diagram and database design with ERD. Analysis is done to get the condition that has been going on (As Is). Furthermore, the authors formulate the functional requirements that must be owned by the system to handle the constraints that occur today. PRABA is implemented based on website with PHP programming language and MySQL database. The test result on PRABA using black box testing method indicates that PRABA has fulfilled functional requirements that have been set related to achievement data management and scholarship.
\end{abstract}

Keywords : Achievements, Scholarships, Management Information Systems

\section{PENDAHULUAN}

Salah satu inti utama kegiatan manajemen perguruan tinggi adalah pengelolaan dan peningkatan potensi mahasiswa. Begitu pentingnya pengelolaan mahasiswa ini membuat BAN-PT mengeluarkan sebuah standar pedoman evaluasi diri bagi seluruh jurusan atau program studi pada perguruan tinggi di Indonesia yang salah satu komponennya 
fokus membahas informasi mengenai mahasiswa/ kemahasiswaan dan lulusan (Pradnyana \& Sugihartini, 2016).

Berbagai cara dilakukan untuk dapat menjaga dan meningkatkan mutu pendidikan di perguruan tinggi khususnya bidang mahasiswa/ kemahasiswaan, salah satunya adalah dengan pemberian beasiswa bagi mahasiswa yang berprestasi maupun beasiswa bagi mahasiswa yang tidak mampu. Harapannya dengan beasiswa, proses pendidikan dapat terus berlangsung dan meningkatnya prestasi mahasiswa. Universitas Pendidikan Ganesha (Undiksha) sebagai salah satu lembaga pendidikan memperoleh berbagai jenis bantuan beasiswa yang ditawarkan oleh donatur beasiswa di antaranya: Supersemar, PPA, Bantuan Belajar Mahasiswa (BBM), Beasiswa Bank Indonesia, Beasiswa Jembrana, Beasiswa LIPPO Bank, dan lain-lain. Proses pengelolaan beasiswa dilakukan oleh bagian kemahasiswaan di tingkat rektorat dan di bagian kemahasiswaan di tingkat fakultas.

Berdasarkan hasil wawancara awal penulis pada bagian kemahasiswaan khususnya pengelola beasiswa di Fakultas Teknik dan Kejuruan (FTK) Undiksha, diperoleh informasi bahwa pengelolaan dalam hal ini administrasi beasiswa belum didukung oleh aplikasi atau sistem. Semua proses dikerjakan secara konvensional. Selama ini, berkas pengajuan yang dikumpulkan mahasiswa hanya dalam bentuk hardcopy saja. Setelah proses seleksi selesai, berkas tersebut dikembalikan ke mahasiswa. fakultas tidak memiliki salinan berkas tersebut, yang disimpan hanyalah rekap hasil seleksi beasiswa. Permasalahan yang biasanya terjadi yaitu pengelola beasiswa membutuhkan waktu pencarian berkas rekapitulasi yang cukup lama karena harus dicari terlebih dahulu dalam lemari berkas. Pencarian bisa menjadi lebih lama apabila sempat terjadi pergantian/ perpindahan staff pegawai. Selain itu, pihak fakultas juga harus berhati-hati dan harus dapat mencegah seorang mahasiswa memperoleh lebih dari satu jenis beasiswa pada periode yang sama. Selanjutnya, berkaitan erat dengan beasiswa, fakultas juga tidak memiliki dokumentasi yang lengkap mengenai prestasi-prestasi yang dimiliki oleh mahasiswa. Selama ini, prestasiprestasi yang dimiliki oleh mahasiswa tidak dikelola dengan baik. Dokumentasi mengenai prestasi tercecer dan tidak terjadi sinkronisasi atau kesamaan pembaharuan data baik di tingkat jurusan, fakultas dan bahkan rektorat yang dibuktikan berbedanya data prestasi yang dimiliki oleh masing-masing tingkatan tersebut. Sampai saat ini, belum ada sistem yang mengelola data dokumentasi prestasi-prestasi mahasiswa sehingga dapat diakses dengan cepat, valid dan sinkron baik di tingkat jurusan, fakultas maupun rektorat. Padahal dokumentasi bidang kemahasiswaan khususnya data prestasi dan pengelolaan beasiswa sangat penting terutama ketika proses akreditasi (Faturrahman, Sholiq, \& Muqtadiroh, 2013).

Selain melakukan wawancara dengan pengelola, penulis juga melakukan pengumpulan informasi awal dengan beberapa mahasiswa yang pernah mengajukan dan menerima maupun yang tidak menerima beasiswa untuk mendapat informasi yang lebih lengkap dari sudut pandang yang berbeda. Menurut mereka, masalah yang sering terjadi yaitu pendeknya waktu mempersiapkan berkas lamaran beasiswa. Hal tersebut diakibatkan karena panjangnya alur birokrasi penyampaian pengumuman beasiswa yaitu dari rektorat ke pihak fakultas, dari fakultas ke jurusan dan selanjutnya pihak jurusan mengumumkan kepada mahasiswa. Selain itu, mahasiswa juga merasakan proses yang tidak efisien, terutama bagi mahasiswa yang tidak lulus dalam seleksi beasiswa. Ketika mereka tidak lulus dan akan mengajukan berkas untuk jenis beasiswa lainnya, mereka diminta mengumpulkan beberapa syarat yang serupa dengan pengajuan beasiswa sebelumnya. Permasalahan lainnya adalah tidak diketahuinya jumlah pelamar beasiswa tersebut, apakah sudah mencapai kuota atau sebaliknya kuota belum terpenuhi. Hal lainnya yang menjadi keluhan adalah tidak diketahuinya status pengajuan dan seleksi beasiswa secara langsung. Akibatnya, 
mahasiswa harus menunggu tanpa mengetahui status beasiswa yang diajukan.

Berdasarkan beberapa permasalahan tersebut, penulis bertujuan mengembangkan Sistem Informasi Manajemen Prestasi dan Beasiswa Undiksha (PRABA) yang dapat membantu mengelola data prestasi dan beasiswa di lingkungan Undiksha. PRABA dikembangkan berbasis website sehingga mahasiswa dapat mengaksesnya dengan leluasa, di mana dan kapan saja dengan harapan mampu mempercepat penyampaian informasi seleksi beasiswa dan memudahkan dalam melengkapi syarat pengajuan beasiswa termasuk di dalamnya pengumpulan data prestasi. PRABA dikembangkan dengan beberapa fungsional yaitu: (a) dapat mempermudah dan mempercepat mahasiswa untuk mendapatkan informasi penawaran beasiswa, (b) mempermudah pihak fakultas dan Undiksha dalam mendata dan mengelola beasiswa dan calon penerima beasiswa, (c) membantu mendokumentasikan pengumuman seluruh beasiswa dan syarat masing-masing, per periode yang dikelola oleh fakultas dan Undiksha, (d) membantu mendokumentasikan pelamar masingmasing beasiswa per periode beserta syarat yang telah diunggah, (e) membantu mencegah mahasiswa yang tengah dalam status menerima beasiswa untuk mengajukan beasiswa lainnya diperiode yang sama, (f) membantu mendokumentasikan prestasi yang dimiliki oleh mahasiswa secara terintegrasi dengan proses pengajuan beasiswa.

Sistem informasi manajemen (SIM) adalah sistem informasi terkomputerisasi yang dapat bekerja karena interaksi yang memiliki tujuan antara manusia dan komputer. Dengan kolaborasi fungsional antara manusia, perangkat lunak dan perangkat keras, SIM dapat mendukung pengguna dalam menyelesaikan tugas organisasi, termasuk analisis dan pengambilan keputusan. Untuk mendapatkan informasi, pengguna dari SIM saling berbagi basis data. Basis data disimpan berupa data dan model dapat membantu pengguna untuk dapat berinteraksi, menginterpretasikan dan mengakses data tersebut. Hasil dari SIM dapat digunakan untuk mendukung dalam pengambilan keputusan. SIM dapat juga membantu mengintegrasikan beberapa fungsi informasi terkomputerisasi dari organisasi (Kendall \& Kendall, 2011).

Penggunaan sistem informasi manajemen diperlukan untuk memfasilitasi prosedur kerja dan meningkatkan efisiensi dan produktivitas serta meningkatkan kinerja organisasi secara umum (Almamary, Shamsuddin, \& Aziati, 2014). Selain itu, penggunaan aplikasi atau sistem bertujuan untuk memberikan kemudahankemudahan yang antara lain lebih kemudahan dalam mengelola data yang ada. Dengan adanya manajemen data yang lebih baik tersebut nantinya juga memberikan manfaat apabila data tersebut dibutuhkan untuk diolah untuk berbagai keperluan, misalnya untuk keperluan pengambilan keputusan sehingga dapat membantu perguruan tinggi mencapai visi dan misi yang sudah ditetapkan (Aprida \& Samopa, 2013).

\section{METODE}

Penelitian ini merupakan penelitian pengembangan yang hasil akhirnya berupa prototipe perangkat lunak sistem informasi. Metode penelitian yang digunakan ditunjukkan pada gambar 1 .

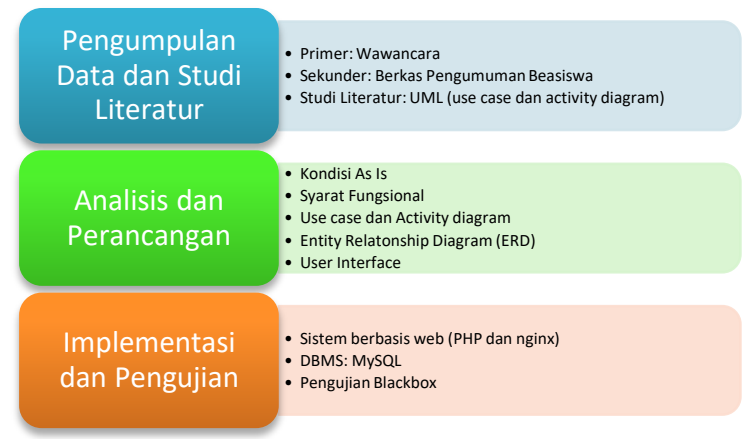

Gambar 1. Metode Penelitian

Metode penelitian yang digunakan yaitu sebagai berikut:

1. Pengumpulan Data dan Studi Literatur. Data yang digunakan pada penelitian ini adalah data primer dan data sekunder. Data primer yaitu data yang diperolah secara langsung Jurnal Sains dan Teknologi | 39 
melalui beberapa kali wawancara dengan staff pegawai yang bertugas mengelola beasiswa di FTK Undiksha. Wawancara juga dilakukan dengan mahasiswa yang pernah mengajukan, lulus maupun tidak lulus beasiswa. Kedua wawancara yang penulis lakukan termasuk wawancara semi terstruktur. Penulis hanya menyiapkan garis besar pertanyaan yang selanjutnya penulis kembangkan sesuai dengan jawaban narasumber. Data sekunder yang penulis berhasil kumpulkan berupa beberapa contoh berkas pengumuman dan metode seleksi beasiswa yang pernah dikelola oleh FTK Undiksha. Untuk dapat melakukan analisis dan perancangan, penulis mengkaji literatur mengenai pengembagan sistem informasi menggunakan pendekatan berorientasi objek khususnya perancangan dengan diagram use case dan aktivitas. Selain itu, penulis juga melakukan kajian teori mengenai perancangan basis data dengan Entity Relationship Diagram (ERD).

2. Analisis Data dan Perancangan Sistem. Data yang sudah dikumpulkan pada tahap sebelumnya kemudian dianalisis untuk mendapatkan kondisi yang selama ini berjalan (As-ls) pada proses pengajuan dan pengelolaan prestasi dan beasiswa. Selanjutnya penulis merumuskan syarat fungsional sistem dengan menggunakan diagram use case, merancang kondisi kedepannya ketika sistem diterapkan ( $T o \mathrm{Be}$ ) dengan menggunakan diagram aktivitas, merancang user interface sistem serta merancang basis data menggunakan ERD.

3. Implementasi dan Pengujian. Hasil analisis dan perancangan diimplementasikan dengan perangkat lunak PHP versi 7.1, nginx dan MySQL. Setelah diimplementasikan menjadi sistem informasi, penulis melakukan pengujian dengan metode black box untuk menguji kepatuhan dan kesesuaian syarat fungsional pada saat perancangan dengan implementasinya.

\section{HASIL DAN PEMBAHASAN}

Pada bagian ini, penulis membahas hasil analisis dan perancangan, implementasi, dan pengujian prototipe PRABA.

\section{Analisis dan Perancangan}

Hasil analisis dan perancangan berupa syarat fungsional sistem ditunjukkan dengan diagram use case seperti ditunjukkan pada gambar 2 .

Pada diagram use case tersebut ditunjukkan bahwa aktor yang berinteraksi dengan PRABA dibagi menjadi empat yaitu Admin Universitas, Operator Fakultas, Pengunjung dan Mahasiswa. Sistem memiliki syarat fungsional yang harus dipenuhi untuk masing-masing aktor yaitu:

1. Admin Universitas adalah staff pegawai pada bidang kemahasiswaan di rektorat yang bertugas mengelola artikel, jenis beasiswa, penawaran dan pengumuman beasiswa. Persyaratan fungsional yang harus dimiliki sistem untuk admin yaitu: (a) Sistem dapat mengelola (menambah, mengubah, menghapus, menampilkan) akun pengguna. (b) Sistem dapat mengelola (menambah, mengubah, menampilkan) artikel. (c) Sistem dapat mengelola (menambah, mengubah, menghapus, menampilkan) informasi beasiswa seperti jenis beasiswa, tahap seleksi beasiswa, jenis berkas beasiswa. (d) Sistem dapat mengelola (menambah, mengubah, menghapus, menampilkan) penawaran beasiswa seperti nama beasiswa, periode, tenggat waktu pengajuan, scan surat pengumuman beasiswa. dan kuota beasiswa. (e) Sistem dapat mengelola (menambah, mengubah, menghapus, menampilkan) pengumuman penerimaan beasiswa untuk masingmasing pelamar. (f) sistem dapat mencetak daftar pelamar dan penerima beasiswa berdasarkan periode dan nama beasiswa. 


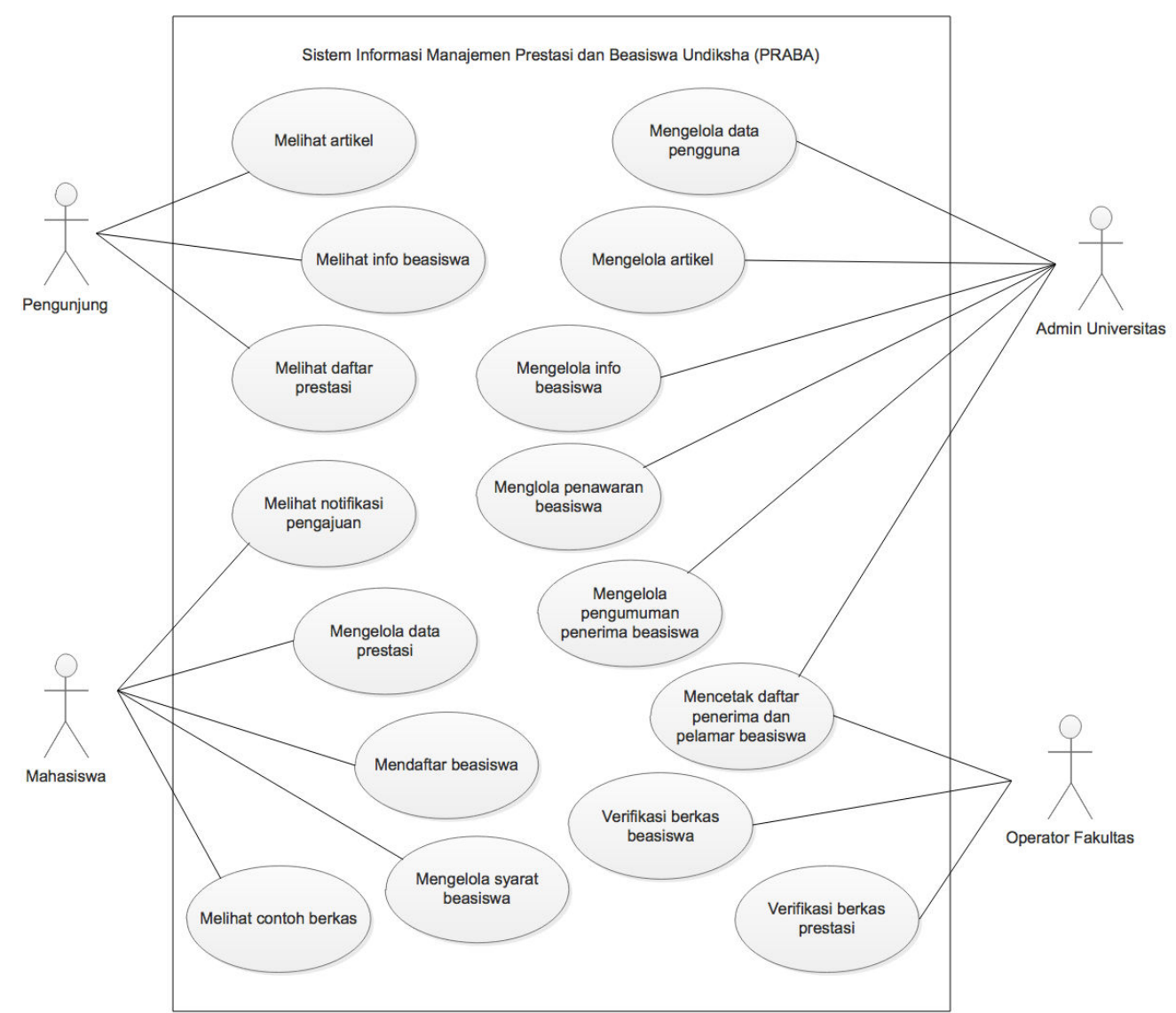

Gambar 2. Diagram Use Case PRABA

2. Operator Fakultas adalah pegawai bidang kemahasiswaan yang bertugas memverifikasi berkas prestasi dan pengajuan beasiswa di masing-masing fakultas. Persyaratan fungsional yang harus dimiliki sistem untuk operator yaitu: (a) Sistem dapat memverifikasi berkas softcopy pengajuan beasiswa yang diajukan mahasiswa calon penerima beasiswa - (b) Sistem dapat memverifikasi softcopy berkas prestasi yang diunggah mahasiswa. (c) Sistem dapat mencetak daftar pelamar dan penerima beasiswa berdasarkan nama beasiswa dan periode/ tahun ajar

3. Mahasiswa adalah pengguna sistem yang dapat mengunggah softcopy berkas prestasi dan berkas pengajuan beasiswa. Persyaratan fungsional yang harus dimiliki sistem untuk mahasiswa yaitu: (a) Sistem dapat mengelola (menambah, mengubah, menghapus, menampilkan) data prestasi mahasiswa. (b) Sistem dapat melakukan pendaftaran sebagai calon penerima beasiswa untuk beasiswa yang masih dibuka (masih dalam status proses pengajuan). (c) Sistem dapat mengelola (menambah, mengubah, menghapus, menampilkan) syarat yang diajukan atau diunggah mahasiswa. (d) Sistem dapat memberikan notifikasi atau status pengajuan beasiswa (verifikasi fakultas dan diterima). (e) Sistem dapat menampilkan contoh berkas syarat beasiswa dan bisa diunduh.

4. Pengunjung adalah pengguna yang dapat mengunjungi website dan dapat membaca informasi dari artikel-artikel tentang beasiswa, membaca informasi penawaran 
beasiswa dan membaca daftar prestasi tanpa perlu login. Persyaratan fungsional yang harus dimiliki sistem untuk pengunjung yaitu: (a) Sistem mampu menampilkan artikelartikel yang diposting oleh admin universitas. (b) Sistem mampu menampilkan informasi mengenai beasiswa seperti nama beasiswa, periode pengajuan, status pengajuan, kuota penerima, jumlah pelamar, syarat beasiswa serta scan surat resmi mengenai beasiswa tersebut. (c) Sistem mampu menampilkan daftar prestasi yang sudah diunggah oleh mahasiswa dan sudah diverifikasi oleh operator di masing-masing fakultas.

Pada penelitian ini, proses perancangan basis data menggunakan ERD. Perancangan basis data dilakukan secara bertahap mulai dari model konseptual, logis dan terakhir fisik. Perancangan basis data konseptual dilakukan dengan mengidentifikasi identifikasi entitas, relasi, konstrain dan kardinalitas (Pradnyana, Permana, \& Putrama, 2017). Perancangan basis data konseptual diperbaiki dan dilengkapi lebih rinci dengan tipe data pada MySQL yang dipilih sebagai DBMS implementasi basis data PRABA. Hasil akhir rancangan basis data adalah tabel-tabel yang berelasi. Tampilan rancangan relasi antar tabel dari basis data PRABA ditunjukkan pada gambar 3.

\section{Implementasi}

Tampilan interface PRABA dijelaskan sebagai per aktor sebagai berikut:

1. Admin Universitas

Admin bertugas mengelola pengguna sistem yang terdiri dari mahasiswa, operator fakultas dan admin sendiri. Tampilan untuk mengelola pengguna PRABA ditunjukkan pada gambar 4 .

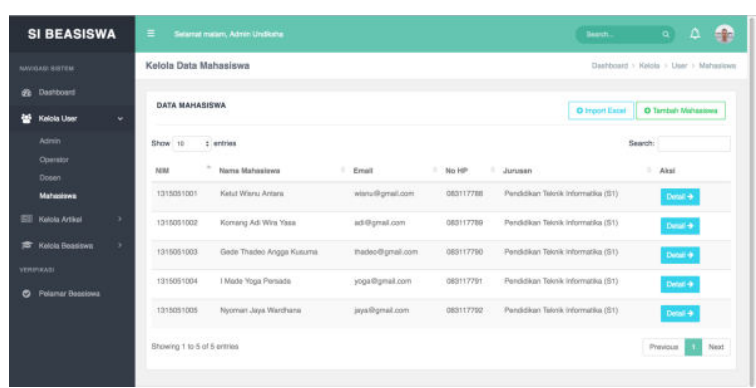

Gambar 4. Tampilan mengelola pengguna 


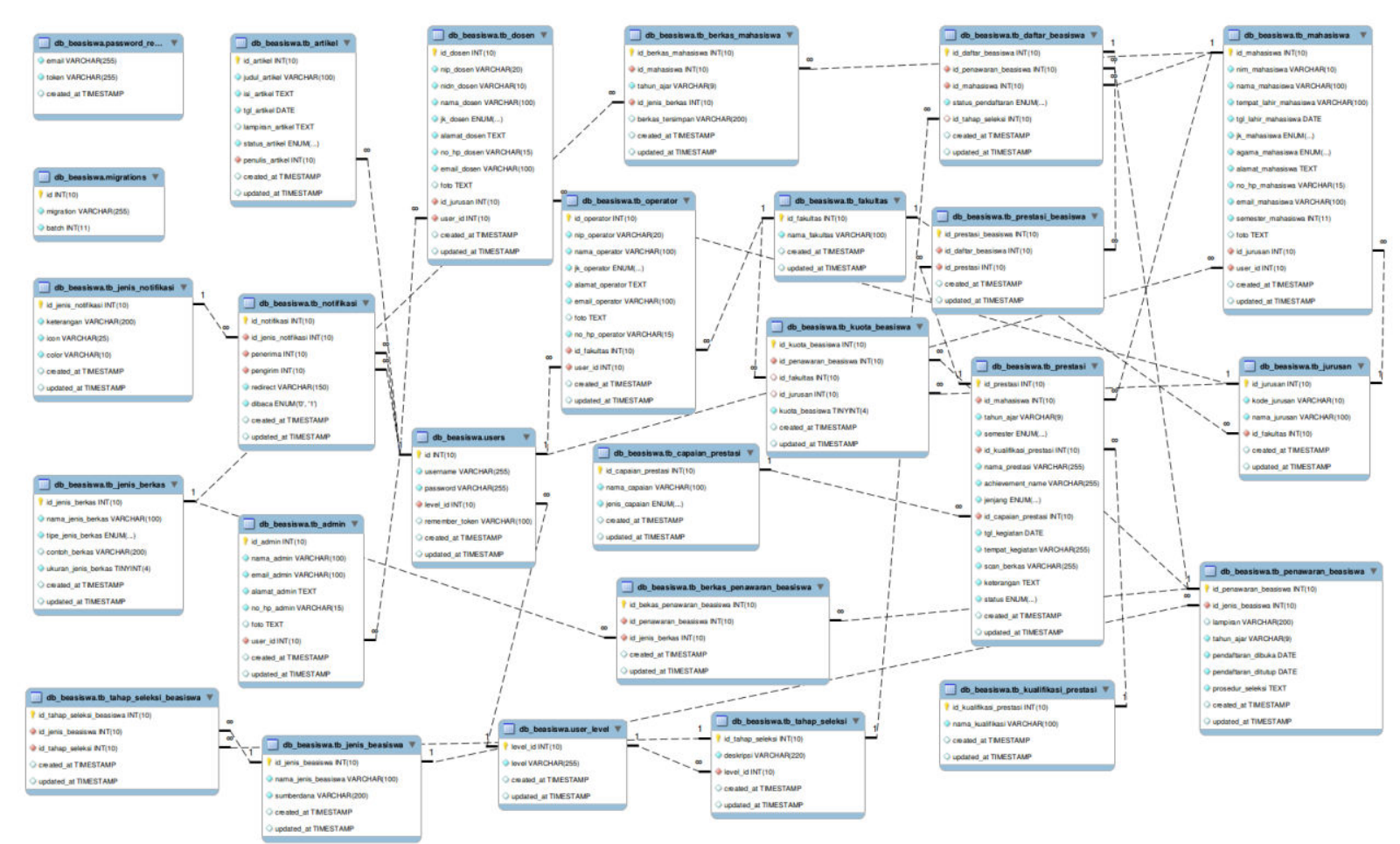

Gambar 3. Relasi Antar Tabel Sistem PRABA

Admin juga melakukan pengelolaan artikel yang berkaitan dengan prestasi dan beasiswa yang dikelola Undiksha. Tampilan untuk kelola artikel ditunjukkan pada gambar 5.

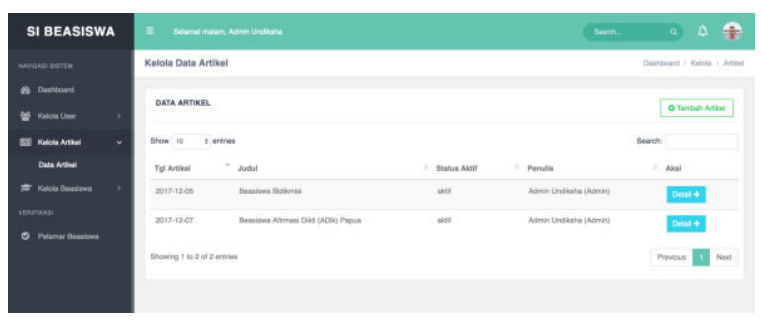

Gambar 5. Tampilan mengelola artikel

Admin dapat mengelola jenis beasiswa dengan menambah nama beasiswa, nama donatur serta tahapan seleksi yang akan dilakukan apakah dikelola fakultas atau di tingkat universitas. Tampilan untuk mengelola jenis beasiswa ditunjukkan pada gambar 6 .

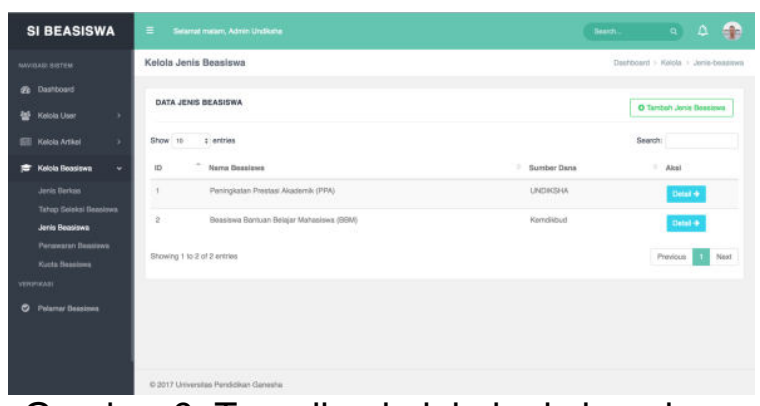

Gambar 6. Tampilan kelola jenis beasiswa

Admin dapat mengelola tahapan seleksi beasiswa sesuai dengan tampilan pada gambar 7. Sesuai dengan proses bisnis yang ada, ada dua jenis tahapan seleksi beasiswa yang ditangani di PRABA yaitu verifikasi oleh operator fakultas dan verifikasi oleh admin universitas.

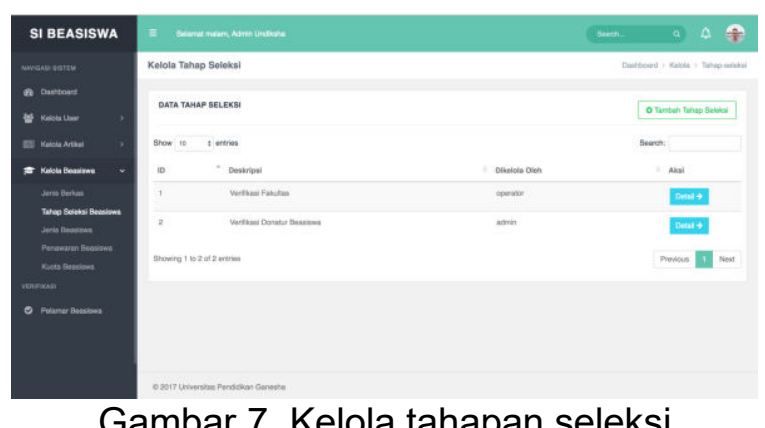

Gambar 7. Kelola tahapan seleksi 
Berkas yang harus diunggah oleh calon penerima besiswa disertakan pada saat penawaran beasiswa. Tampilan pengelolaan berkas penawaran beasiswa ditunjukkan pada gambar 8 .

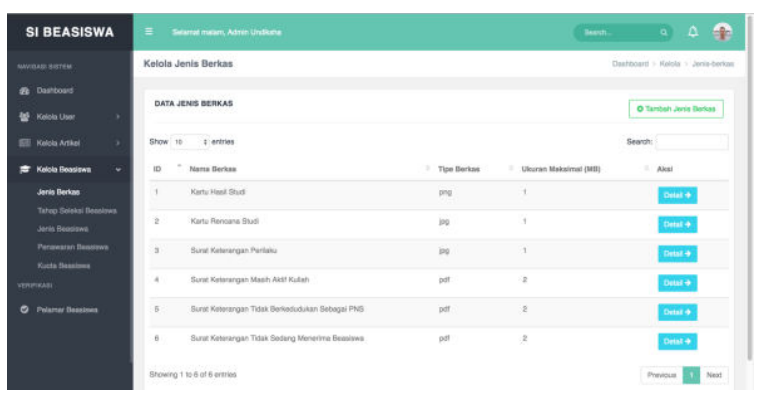

Gambar 8. Kelola berkas beasiswa

Tampilan kelola penawaran beasiswa ditunjukkan pada gambar 9. Admin dapat mengumumkan penawaran dengan melengkapi identitas jenis beasiswa, tahun ajaran, tenggat waktu mulai dan penutupan pendaftaran, jenis berkas yang harus diunggah, lampiran pengumuman resmi serta penjelasan seleksi beasiswa. Kuota untuk penawaran beasiswa ditunjukkan pada gambar 10. Admin dapat menentukan kuota beasiswa per jurusan yang ada di Undiksha.

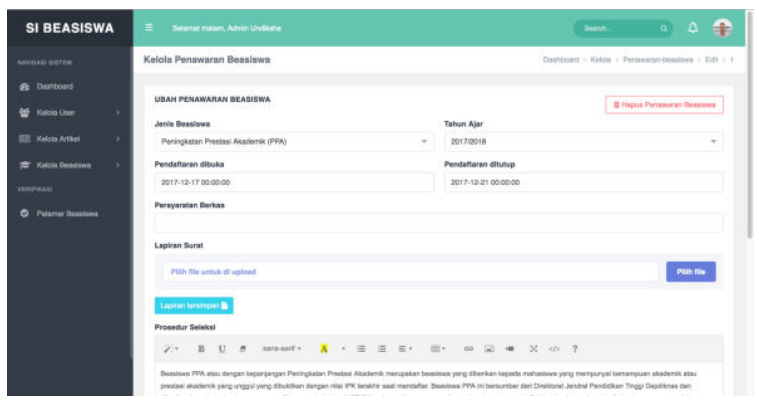

Gambar 9. Tampilan kelola penawaran beasiswa

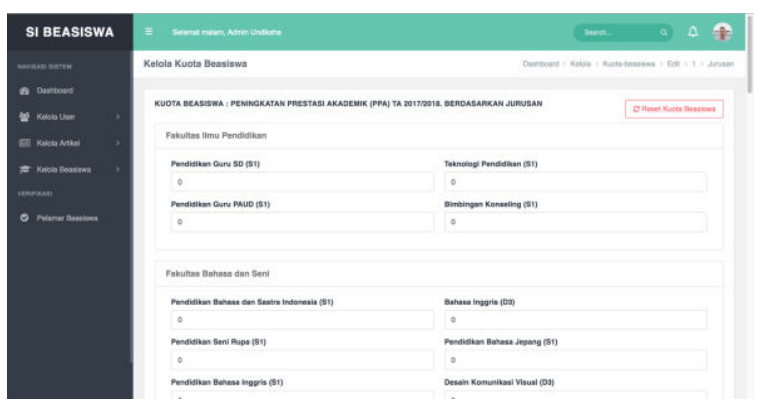

Gambar 10. Tampilan kelola kuota penawaran beasiswa
2. Operator Fakultas

Operator di masing-masing fakultas bertugas memverifikasi berkas prestasi dan berkas pengajuan beasiswa yang diunggah mahasiswa. Tampilan untuk rekapitulasi pengajuan beasiswa, detail penawaran beasiswa dan pelamarnya, serta daftar prestasi yang diajukan mahasiswa ditunjukkan pada gambar 11, 12, dan 13.

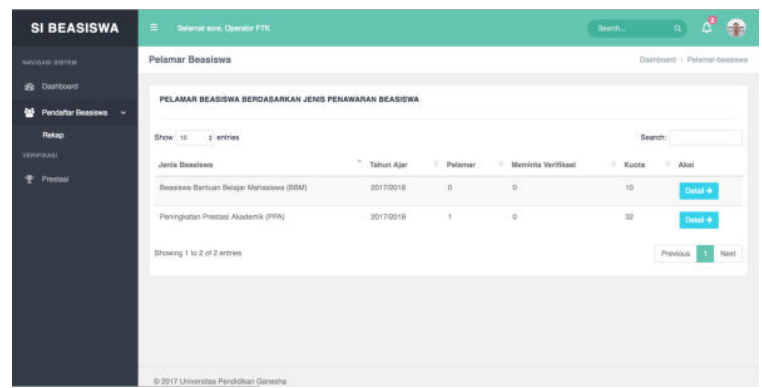

Gambar 11. Rekapitulasi jenis dan pelamar beasiswa

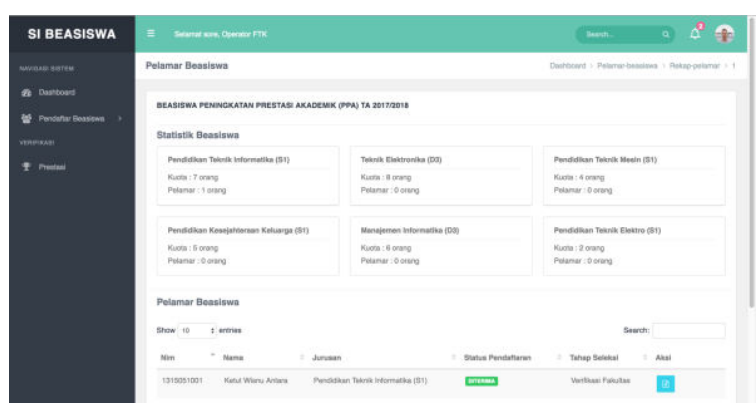

Gambar 12. Tampilan detail salah satu jenis beasiswa

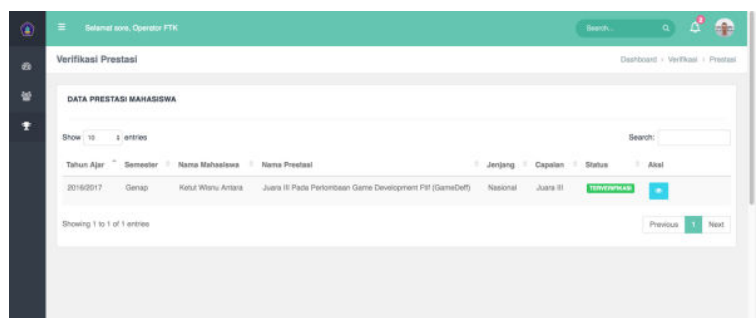

Gambar 13. Tampilan daftar prestasi yang diunggah mahasiswa

\section{Mahasiswa}

Mahasiswa dapat mengajukan diri (mendaftar) sebagai calon penerima beasiswa melalui PRABA. Untuk dapat mendaftarkan diri sebagai calon penerima beasiswa, mahasiswa harus mengisi daftar prestasi terlebih dahulu. Mahasiswa yang berstatus sedang menerima beasiswa tidak dapat lagi mengajukan diri sebagai calon 
penerima beasiswa. Untuk dapat melakukan mendaftar beasiswa dan mendaftarkan prestasi, mahasiswa harus login terlebih dahulu. Tampilan daftar beasiswa yang masih dibuka maupun sudah ditutup, tampilan untuk mendaftar beasiswa, mendaftarkan prestasi dan tampilan yang menyatakan mahasiswa lulus atau menerima beasiswa ditunjukkan pada gambar 14, 15, 16 dan 17.

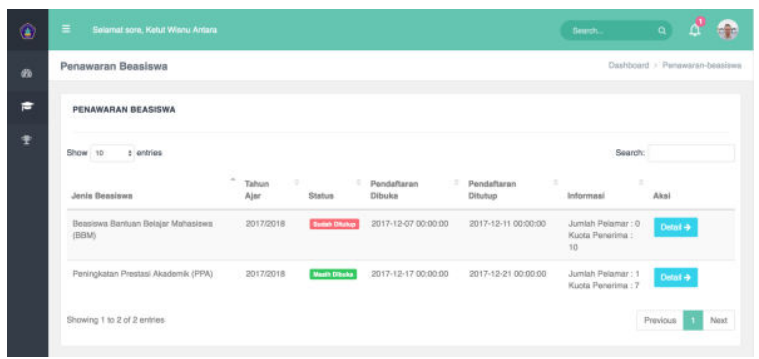

Gambar 14. Daftar penawaran beasiswa

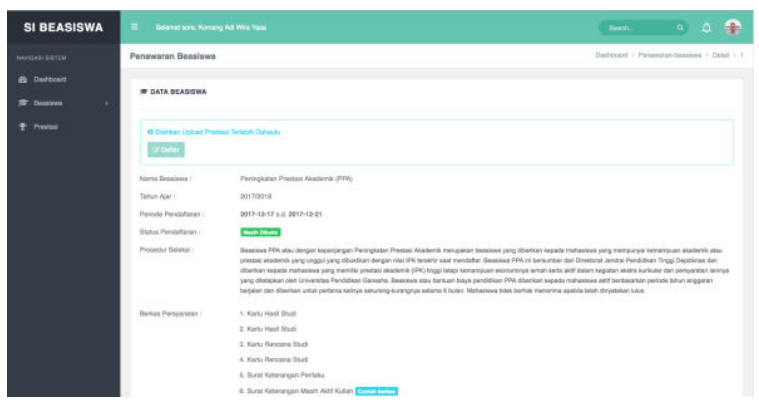

Gambar 15. Tampilan penawaran beasiswa yang dapat dilamar

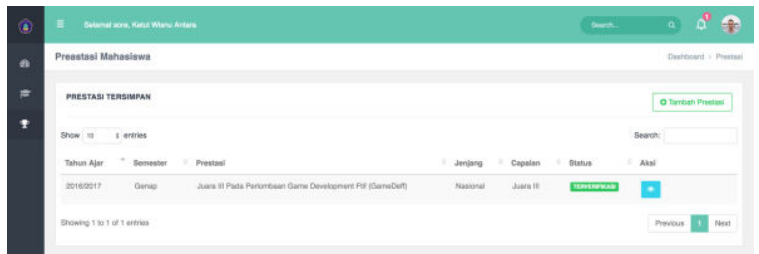

Gambar 16. Tampilan daftar prestasi yang dikelola mahasiswa

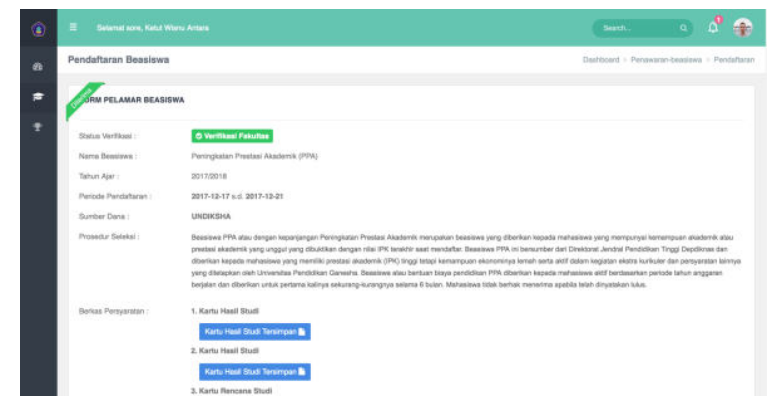

Gambar 17. Tampilan mahasiswa lulus menerima beasiswa

\section{Pengunjung}

Pengunjung dapat melihat artikel atau berita yang berkaitan dengan beasiswa dan prestasi mahasiswa Undiksha, melihat informasi penawaran beasiswa yang dikelola Undiksha dan daftar prestasi yang dimiliki mahasiswa Undiksha. Tampilan untuk halaman yang dapat dilihat oleh pengunjung ditunjukkan pada gambar 18 , 19 dan 20.

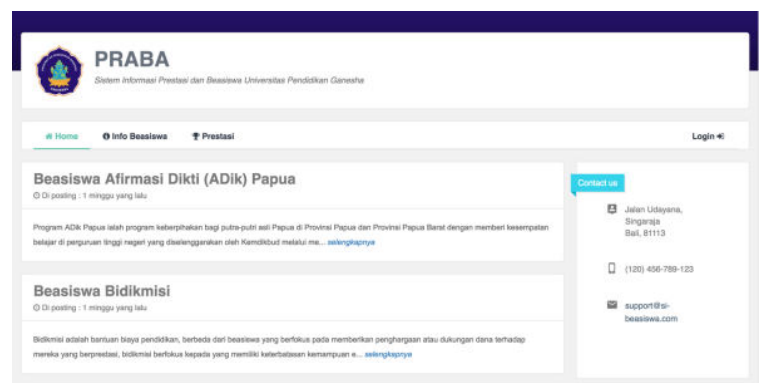

Gambar 18. Daftar artikel tentang beasiswa dan prestasi mahasiswa Undiksha

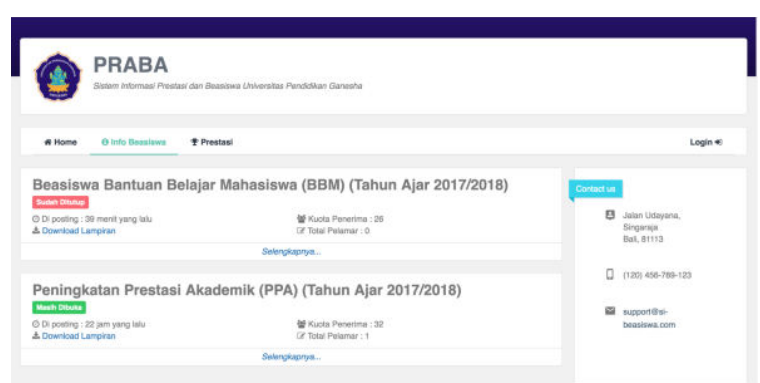

Gambar 19. Daftar penawaran beasiswa yang dikelola Undiksha

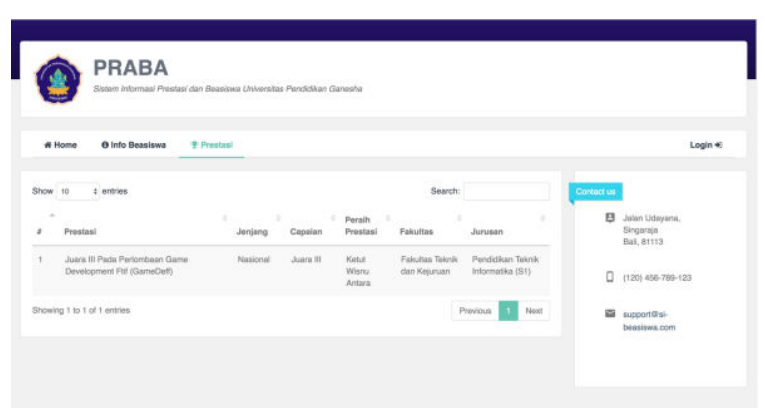

Gambar 20. Daftar prestasi mahasiswa Undiksha

\section{Pengujian}

Pengujian terhadap PRABA dilakukan menggunakan teknik pengujian black box. Rancangan pengujian black box mengacu pada syarat fungsional sistem yang sudah ditetapkan pada saat analisis dan Jurnal Sains dan Teknologi | 45 
perancangan. Pada penelitian ini, ketika ditemukan kesalahan implementasi syarat fungsionalitas, PRABA diperbaiki sampai syarat fungsional terpenuhi. Berdasarkan hasil pengujian didapat kesimpulan bahwa
PRABA sudah memenuhi syarat fungsional yang ditetapkan sebelumnya. Rangkuman katagori, skenario dan hasil pengujian black box ditunjukkan pada tabel 1.

Tabel 1. Rangkuman hasil pengujian black box

\begin{tabular}{|c|c|c|c|c|}
\hline No. & Katagori & Skenario & Hasil yang diharapkan & $\begin{array}{c}\text { Kesimpulan } \\
\text { pengujian }\end{array}$ \\
\hline 1 & Login Admin & $\begin{array}{llr}\text { Akun Admin } & \text { diuji } & \text { coba } \\
\text { untuk login } & \text { ke sistem } \\
\text { dengan } & \text { kombinasi } \\
\text { username dan/ } & \text { atau } \\
\text { password yang salah dan } \\
\text { benar. }\end{array}$ & $\begin{array}{l}\text { Sistem hanya memberikan } \\
\text { akses login r untuk } \\
\text { username dan password } \\
\text { yang benar. }\end{array}$ & Sesuai \\
\hline 2 & $\begin{array}{l}\text { Kelola } \\
\text { pengguna }\end{array}$ & $\begin{array}{l}\text { Akun Admin diuji coba } \\
\text { untuk } \\
\text { mengubah, menambah, } \\
\text { akun pengguna operator } \\
\text { fakultas dan mahasiswa. }\end{array}$ & $\begin{array}{l}\text { Sistem dapat menambah, } \\
\text { mengubah, menghapus } \\
\text { akun pengguna operator } \\
\text { fakultas dan mahasiswa }\end{array}$ & Sesuai \\
\hline 3 & Kelola artikel & $\begin{array}{ll}\text { Akun Admin diuji coba } \\
\text { untuk } & \text { menambah, } \\
\text { mengubah, } & \text { menghapus } \\
\text { artikel. } & \end{array}$ & $\begin{array}{l}\text { Sistem dapat menambah, } \\
\text { mengubah, menghapus } \\
\text { artikel. }\end{array}$ & Sesuai \\
\hline 4 & $\begin{array}{l}\text { Kelola info } \\
\text { beasiswa }\end{array}$ & $\begin{array}{l}\text { Akun Admin diuji coba } \\
\text { untuk menambah, } \\
\text { mengubah, menghapus } \\
\text { informasi beasiswa seperti } \\
\text { jenis beasiswa, tahap } \\
\text { seleksi beasiswa, jenis } \\
\text { berkas beasiswa. }\end{array}$ & $\begin{array}{l}\text { Sistem dapat menambah, } \\
\text { mengubah, menghapus } \\
\text { informasi beasiswa seperti } \\
\text { jenis beasiswa, tahap } \\
\text { seleksi beasiswa, jenis } \\
\text { berkas beasiswa }\end{array}$ & Sesuai \\
\hline 5 & $\begin{array}{l}\text { Kelola } \\
\text { penawaran } \\
\text { beasiswa }\end{array}$ & $\begin{array}{l}\text { Akun Admin diuji coba } \\
\text { untuk menambah, } \\
\text { mengubah, menghapus } \\
\text { penawaran beasiswa } \\
\text { seperti nama beasiswa, } \\
\text { periode, tenggat waktu } \\
\text { pengajuan, scan surat } \\
\text { pengumuman beasiswa } \\
\text { dan kuota beasiswa. }\end{array}$ & $\begin{array}{l}\text { Sistem dapat menambah, } \\
\text { mengubah, menghapus } \\
\text { penawaran beasiswa } \\
\text { seperti nama beasiswa, } \\
\text { periode, tenggat waktu } \\
\text { pengajuan, scan surat } \\
\text { pengumuman beasiswa } \\
\text { dan kuota beasiswa. }\end{array}$ & Sesuai \\
\hline 6 & $\begin{array}{l}\text { Kelola } \\
\text { pengumuman } \\
\text { penerima } \\
\text { beasiswa }\end{array}$ & $\begin{array}{l}\text { Akun Admin diuji coba } \\
\text { untuk menambah, } \\
\text { mengubah, menghapus } \\
\text { pengumuman penerimaan } \\
\text { beasiswa untuk masing- } \\
\text { masing pelamar. }\end{array}$ & $\begin{array}{l}\text { Sistem dapat menambah, } \\
\text { mengubah, menghapus } \\
\text { pengumuman penerimaan } \\
\text { beasiswa untuk masing- } \\
\text { masing pelamar. }\end{array}$ & Sesuai \\
\hline 7 & $\begin{array}{l}\text { Mencetak } \\
\text { daftar } \\
\text { penerima } \\
\text { beasiswa }\end{array}$ & $\begin{array}{l}\text { Akun Admin diuji coba } \\
\text { untuk dapat mencetak } \\
\text { daftar pelamar dan } \\
\text { penerima } \\
\text { berdasarkan periode dan } \\
\text { nama beasiswa. }\end{array}$ & $\begin{array}{l}\text { Sistem dapat mencetak } \\
\text { daftar pelamar dan } \\
\text { penerima beasiswa } \\
\text { berdasarkan periode dan } \\
\text { nama beasiswa. }\end{array}$ & Sesuai \\
\hline 8 & Login & Akun Operator diuji coba & Sistem hanya memberikan & Sesuai \\
\hline
\end{tabular}




\begin{tabular}{|c|c|c|c|c|}
\hline No. & Katagori & Skenario & Hasil yang diharapkan & $\begin{array}{c}\text { Kesimpulan } \\
\text { pengujian }\end{array}$ \\
\hline & $\begin{array}{l}\text { Operator } \\
\text { Fakultas }\end{array}$ & $\begin{array}{l}\text { untuk login ke sistem } \\
\text { dengan } \\
\text { username dan/ atau } \\
\text { password yang salah dan } \\
\text { benar. }\end{array}$ & $\begin{array}{l}\text { akses login untuk } \\
\text { username dan password } \\
\text { yang benar. }\end{array}$ & \\
\hline 9 & $\begin{array}{l}\text { Verifikasi } \\
\text { berkas } \\
\text { pengajuan } \\
\text { beasiswa }\end{array}$ & $\begin{array}{l}\text { Akun Operator diuji coba } \\
\text { untuk verifikasi berkas } \\
\text { softcopy pengajuan } \\
\text { beasiswa yang diajukan } \\
\text { mahasiswa calon penerima } \\
\text { beasiswa. }\end{array}$ & $\begin{array}{lr}\text { Sistem } & \text { dapat } \\
\text { memverifikasi } & \text { berkas } \\
\text { softcopy pengajuan } \\
\text { beasiswa yang diajukan } \\
\text { mahasiswa calon penerima } \\
\text { beasiswa. }\end{array}$ & Sesuai \\
\hline 10 & $\begin{array}{l}\text { Verifikasi } \\
\text { prestasi } \\
\text { mahasiswa }\end{array}$ & $\begin{array}{l}\text { Akun Operator diuji coba } \\
\text { untuk verifikasi softcopy } \\
\text { berkas prestasi yang } \\
\text { diunggah mahasiswa. }\end{array}$ & $\begin{array}{l}\text { Sistem dapat } \\
\text { memverifikasi softcopy } \\
\text { berkas prestasi yang } \\
\text { diunggah mahasiswa. }\end{array}$ & Sesuai \\
\hline 11 & $\begin{array}{l}\text { Mencetak } \\
\text { data pelamar } \\
\text { dan penerima } \\
\text { beasiswa }\end{array}$ & $\begin{array}{l}\text { Akun Operator diuji coba } \\
\text { untuk mencetak daftar } \\
\text { pelamar dan penerima } \\
\text { beasiswa berdasarkan } \\
\text { nama beasiswa dan } \\
\text { periode/ tahun ajar. }\end{array}$ & 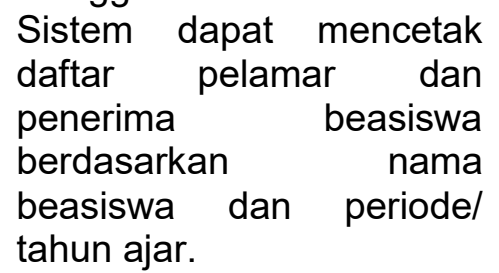 & Sesuai \\
\hline 12 & $\begin{array}{l}\text { Login } \\
\text { Mahasiswa }\end{array}$ & $\begin{array}{l}\text { Akun Mahasiswa diuji coba } \\
\text { untuk login ke sistem } \\
\text { dengan kombinasi } \\
\text { username dan/ atau } \\
\text { password yang salah dan } \\
\text { benar. }\end{array}$ & $\begin{array}{l}\text { Sistem hanya memberikan } \\
\text { akses login untuk } \\
\text { username dan password } \\
\text { yang benar. }\end{array}$ & Sesuai \\
\hline 13 & $\begin{array}{l}\text { Mengelola } \\
\text { data prestasi }\end{array}$ & $\begin{array}{l}\text { Akun Mahasiswa diuji coba } \\
\text { untuk menambah, } \\
\text { mengubah, menghapus } \\
\text { data prestasi mahasiswa. }\end{array}$ & $\begin{array}{l}\text { Sistem dapat menambah, } \\
\text { mengubah, menghapus } \\
\text { data prestasi mahasiswa }\end{array}$ & Sesuai \\
\hline 14 & $\begin{array}{l}\text { Kelola } \\
\text { pendaftaran }\end{array}$ & $\begin{array}{l}\text { Akun Mahasiswa diuji coba } \\
\text { untuk melakukan } \\
\text { pendaftaran sebagai calon } \\
\text { penerima beasiswa untuk } \\
\text { beasiswa yang masih } \\
\text { dibuka maupun sudah } \\
\text { ditutup. }\end{array}$ & $\begin{array}{l}\text { Sistem hanya memfasilitas } \\
\text { pengguna untuk dapat } \\
\text { melakukan pendaftaran } \\
\text { sebagai calon penerima } \\
\text { beasiswa untuk beasiswa } \\
\text { yang masih dibuka (masih } \\
\text { dalam status proses } \\
\text { pengajuan). }\end{array}$ & Sesuai \\
\hline 15 & $\begin{array}{l}\text { Kelola } \\
\text { unggah } \\
\text { syarat } \\
\text { beasiswa }\end{array}$ & $\begin{array}{l}\text { Akun Mahasiswa diuji coba } \\
\text { untuk menambah, } \\
\text { mengubah, menghapus } \\
\text { syarat yang diunggah. }\end{array}$ & $\begin{array}{l}\text { Sistem dapat menambah, } \\
\text { mengubah, menghapus } \\
\text { syarat yang diunggah } \\
\text { mahasiswa. }\end{array}$ & Sesuai \\
\hline 16 & $\begin{array}{l}\text { Menerima } \\
\text { dan melihat } \\
\text { notifikasi } \\
\text { status } \\
\text { pengajuan }\end{array}$ & $\begin{array}{l}\text { Akun Mahasiswa diuji coba } \\
\text { untuk melihat notifikasi atau } \\
\text { status pengajuan beasiswa } \\
\text { (verifikasi fakultas dan } \\
\text { diterima). }\end{array}$ & $\begin{array}{l}\text { Sistem dapat memberikan } \\
\text { notifikasi atau status } \\
\text { pengajuan } \\
\begin{array}{l}\text { (verifikasi beasiswa } \\
\text { fakultas dan } \\
\text { diterima). }\end{array}\end{array}$ & Sesuai \\
\hline 17 & $\begin{array}{l}\text { Melihat } \\
\text { contoh } \\
\text { berkas }\end{array}$ & $\begin{array}{l}\text { Akun Mahasiswa diuji coba } \\
\text { untuk melihat contoh } \\
\text { berkas syarat beasiswa }\end{array}$ & $\begin{array}{l}\text { Sistem dapat menampilkan } \\
\text { contoh berkas syarat } \\
\text { beasiswa }\end{array}$ & Sesuai \\
\hline
\end{tabular}




\begin{tabular}{|c|c|c|c|c|}
\hline No. & Katagori & Skenario & Hasil yang diharapkan & $\begin{array}{c}\text { Kesimpulan } \\
\text { pengujian }\end{array}$ \\
\hline 18 & $\begin{array}{l}\text { Melihat } \\
\text { artikel }\end{array}$ & $\begin{array}{l}\text { Pengunjung melihat artikel- } \\
\text { artikel yang diposting. }\end{array}$ & $\begin{array}{l}\text { Sistem dapat menampilkan } \\
\text { artikel-artikel yang } \\
\text { diposting. }\end{array}$ & Sesuai \\
\hline 19 & $\begin{array}{l}\text { Melihat } \\
\text { informasi } \\
\text { detail } \\
\text { beasiswa }\end{array}$ & $\begin{array}{lr}\text { Pengunjung } & \text { melihat } \\
\text { informasi } & \text { mengenai } \\
\text { beasiswa seperti nama } & \text { nama } \\
\text { beasiswa, } & \text { periode } \\
\text { pengajuan, } & \text { status } \\
\text { pengajuan, kuota } & \text { penerima, jumlah pelamar, } \\
\text { sayarat beasiswa serta } \\
\text { scan surat resmi mengenai } \\
\text { beasiswa. }\end{array}$ & 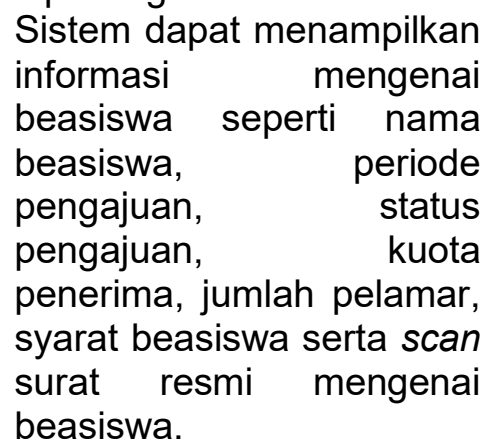 & Sesuai \\
\hline 20 & $\begin{array}{l}\text { Melihat } \\
\text { informasi } \\
\text { prestasi }\end{array}$ & $\begin{array}{l}\text { Pengujung dapat melihat } \\
\text { daftar prestasi mahasiswa. }\end{array}$ & $\begin{array}{l}\text { Sistem mampu } \\
\text { menampilkan daftar } \\
\text { prestasi yang sudah } \\
\text { diunggah oleh mahasiswa } \\
\text { dan diverifikasi oleh } \\
\text { operator di masing-masing } \\
\text { fakultas }\end{array}$ & Sesuai \\
\hline
\end{tabular}

\section{SIMPULAN}

Prototipe sistem informasi manajemen prestasi dan beasiswa Undiksha (PRABA) berhasil dikembangan dan diujikan sehingga sesuai dengan syarat fungsional yang ditetapkan berdasarkan hasil analisis dan perancangan. Metode penelitian yang dilakukan untuk pengembangan PRABA diawali dengan pengumpulan data dan studi literatur, kemudian analisis dan perancangan serta implementasi dan pengujian. Pada penelitian ini, pengujian yang dilakukan baru sebatas pengujian fungsional dengan menggunakan metode black box, kedepannya pengujian bisa dilanjutkan dengan metode lain seperti misalkan pengujian usability dan pengujian penerimaan pengguna. Selain itu, PRABA dapat dikembangkan dan diintegrasikan dengan dengan sistem yang mampu menghasilkan Surat Keterangan Pendamping ljasah (SKPI) sehingga proses kerja menjadi lebih efisien, karena mahasiswa hanya perlu input data prestasi sekali saja dan dapat digunakan untuk berbagai keperluan.

\section{DAFTAR PUSTAKA}

Al-mamary, Y. H., Shamsuddin, A., \& Aziati, N. (2014). The Meaning of Management Information Systems and its Role in Telecommunication

Companies in Yemen. American Journal of Software Engineering., 2(2), 22-25. http://doi.org/10.12691/ajse-2$2-2$

Aprida, C. D., \& Samopa, F. (2013). Pembuatan Sistem Informasi Beasiswa Internal Direktorat Jenderal Perbendaharaan Menggunakan PHP dan MySQL. Jurnal Teknik Pomits, 2(2), 350-354. Retrieved from http://ejurnal.its.ac.id/index.php/teknik/ article/view/4822

Faturrahman, Sholiq, \& Muqtadiroh, F. A. (2013). Rancang Bangun Perangkat Lunak Sistem Kemahasiswaan dan Alumni untuk Pengembangan Sistem Informasi Terintegrasi Sesuai Kebutuhan Pengisian Borang Akreditasi BAN-PT pada Jurusan Sistem Informasi ITS. Jurnal Teknik Pomits, 1(1), 1-5.

Kendall, K. E., \& Kendall, J. E. (2011). System Analysis Design, Eight Edition. New Jersey: Prentice Hal.

Pradnyana, I. M. A., Permana, A. A. J., \& Putrama, I. M. (2017). Implementasi Konsep Perancangan Model Konseptual Basis Data Studi Kasus: Perancangan Basis Data Sistem Informasi Administrasi Beasiswa di 
Undiksha. In Seminar Nasional Vokasi dan Teknologi (SEMNASVOKTEK). (pp. 90-98). Denpasar.

Pradnyana, I. M. A., \& Sugihartini, N. (2016). Analisis dan Perancangan Sistem Informasi Pendukung Data
Kemahasiswaan. In Seminar Nasional Vokasi dan Teknologi (SEMNASVOKTEK) (pp. 296-306). Denpasar. 